ZOOLOGIA 32 (4): 317-320, August 2015

http://dx.doi.org/10.1590/S1984-46702015000400007

SHORT COMMUNICATION

\title{
Approaches to capturing the Black and White Tegu Salvator merianae (Squamata: Teiidae)
}

\author{
Renata C. Vieira ${ }^{1 *}$, Arthur S. de Oliveira ${ }^{1}$, Nelson J.R. Fagundes ${ }^{2} \&$ Laura Verrastro' \\ ${ }^{1}$ Departamento de Zoologia, Universidade Federal do Rio Grande do Sul. Avenida Bento Gonçalves 9500, Prédio 43435, \\ sala 102, Agronomia, 91501-970 Porto Alegre, RS, Brazil. \\ ${ }^{2}$ Departamento de Genética, Universidade Federal do Rio Grande do Sul. Avenida Bento Gonçalves 9500, Prédio 43312, \\ sala 113, Agronomia, 91501-970 Porto Alegre, RS, Brazil. \\ *Corresponding author. E-mail: renatacva@gmail.com
}

\begin{abstract}
The use of traps is extremely important in several types of ecological studies, and may assist in the capture of individuals in areas that are difficult to access. In the present study, we compared the effectiveness of wooden (Schramm) versus "Tomahawk" traps to capture Salvator merianae (Duméril \& Bibron, 1839) lizards. The study was conducted in Eldorado do Sul, Rio Grande do Sul, Brazil. Field data were collected from August 2013 to March 2015, during the reproductive period of the species. The study involved two types of baited traps: i) "Tomahawk", made of galvanized steel; and ii) Schramm, a wooden trap. The capture rate of the Schramm wooden traps was 1.63 individuals/ day, and of the "Tomahawk" was 0.36 individuals/day. These results are important for researchers working with large lizards and may help to increase sampling efficiency for these organisms.
\end{abstract}

KEY WORDS. Capture; ecology; traps; Tomahawk.

The sampling methodology, and its effectiveness, are of primary importance for the acquisition of reliable data (MANGINI $\&$ Nicola 2006). Traps can assist in the capture of animals in areas that are difficult to access and can increase the sampling effort of a given study. Traps can be extremely effective in several types of ecological studies, including faunal inventories, comparisons of relative abundances, studies on population ecology, monitoring of fauna, and in the collection of tissue and blood samples as well as biometrical data (VANZolini \& Papavero 1967, Gibbons \& Semlistsch 1981, Campbell \& Christman 1982, Mengak \& Guynn 1987, Greenberg et al. 1994, Cechin \& Martins 2000, Oliveira et al. 2007). In herpetological studies, particularly those involving reptiles, pitfalls - baited traps made out of pet bottles and PVC tubes - and loop traps - e.g., snare traps - are commonly used (MorTon et al. 1988, SCHEMNITZ 2005).

The choice of a sampling method takes into consideration factors such as the species being studied (and consequently its diet, behavioral traits, and individual body size) and the habitat and topography of the study areas, and logistical restrictions such as the time of sampling and the financial resources available (GARDEN et al. 2007). Consequently, it is difficult to find references that endorse a given method or a combination of methods for all research projects (GARDEN et al. 2007), even for the same species or animal group.

Boxes, cages and snare traps are widely employed in the capture of a wide variety of birds, reptiles and mammals
(MANGini \& Nicola 2006). These traps can be made in different sizes and out of different materials and can have one or more entries (Cechin \& Martins 2000, Reed et al. 2000, Mangini \& Nicola 2006, Souza et al. 2011). Mangini \& Nicola (2006) suggested that some lizard species can be captured using baits and box or cage traps. In this study, we compare between the efficacy of wooden traps (Schramm trap) and "Tomahawk" traps to capture Salvator merianae (Duméril \& Bibron, 1839) lizards.

The study was conducted at the Experimental Agronomic Station of Universidade Federal do Rio Grande do Sul (EAS/ UFRGS), located at Km 146 of BR 290, in Eldorado do Sul, Rio Grande do Sul, Brazil (3005'29"S and 51 $\left.{ }^{\circ} 40^{\prime} 15.4^{\prime \prime} \mathrm{W}\right)$. According to Köeppen's classification, the climate there is subtropical, with warm humid summers (Cfa fundamental type). The average annual rainfall is $1,440 \mathrm{~mm}$, with a monthly average of $120 \mathrm{~mm}$ (BERGAMASCHI \& GUADAGNIN 1990). EAS/UFRGS owns an area of 1,580 ha with open-field vegetation, some areas with dense vegetation, and cultivated areas (Тномаs et al. 1998).

Field data were collected on the weekends from August 2013 to March 2015, which corresponded to the reproductive period of S. merianae lizards (September to March), totaling 5,600 hours of sampling. Given that our objective was to capture individuals for tagging, we selected, as sampling points, places where active lizards had been observed in activity or that were near their shelters and/or burrows. The spatial distribution of the traps was changed periodically during the sampling period

2015 | Sociedade Brasileira de Zoologia | www.sbzoologia.org.br | www.scielo.br/zool All content of the journal, except where identified, is licensed under a Creative Commons attribution-type BY-NC. 
(every weekend), and all traps were checked every hour from 08:00 am to 06:00 pm. The traps were distributed in similar environments: open areas with little herbaceous vegetation and where sun incidence was similar. Some burrows were close to human constructions; however, the traps were on grass, and both models of traps were present in all of the sampling sites at different times. The study involved two types of traps: i) the "Tomahawk", manufactured by Gabrisa Aramados (São Paulo Brazil), which is built from galvanized steel and measures $115 \mathrm{x}$ 55 x $60 \mathrm{~cm}$ (Fig. 1); and ii) the Schramm, a wooden trap, which was developed by us. The Schramm trap is made of four wooden boards $(30 \times 90 \mathrm{~cm})$ on the sides, a bottom that can be open (32 x $27 \mathrm{~cm})$, a door with a closing system $(32 \times 27 \mathrm{~cm})$, and a baiting and triggering system, formed by a wooden batten (71 $\mathrm{cm}$ ) and a wire-based trigger (Fig. 2). There is a screen on the front top of of the Schramm trap $(12 \mathrm{~cm} \times 6 \mathrm{~cm})$, which allows air to enter the trap, making it less stuffy. This screen is made of wire, which also allows the researcher to check for captured animals without the need to open it, generating less stress on the lizards. The entrance of the trap is composed of a free-fall door system that, when armed, is supported by wooden slats and is connected to the firing trigger. When the animal tries to remove the trigger bait, the wooden slats supporting the door are disturbed, closing the trap. The rear door is hinged at the bottom and has a safety pin to prevent the trapped animal from opening it. The main function of this back door is to facilitate the removal of trapped animals (Fig. 2). The "Tomahawk" traps were baited with eggs and bacon, whereas the wooden trap was baited only with bacon due to its triggering system, in which the trigger is attached to the roof of the trap. We chose these baits because $S$. merianae is known to have a generalist and opportunistic diet that includes meat and eggs (WINCK et al. 2011), to which we added the smell of bacon.

Ten "Tomahawk" traps and three wooden traps were used in this study, with a total sampling effort of 5,600 trap/hours: 4,880 hours for the "Tomahawk" traps and 720 hours for the wooden traps. Knowing that the activity of this species is diurnal, we decided to close the traps at night.

The following features of each captured individual were recorded: snout-vent length $(\mathrm{SVL}-\mathrm{cm})$, tail length $(\mathrm{TL}-\mathrm{cm})$, body mass (g), and sex (determined through secondary traits) as well as tail regeneration and/or the absence of phalanges (the latter data were collected to visually assist the identification of individuals). All captured animals were marked with numbered tags and released in the same place where they had been captured. The place of capture of each lizard was geo-referenced using a GPS (Global Positioning System). We also recorded the time of capture and the substrate temperature $\left({ }^{\circ} \mathrm{C}\right)$ of the trap location.

The capture effort of each model of trap throughout the study was calculated by summing the field hours of that type of trap and multiplying it by the number of traps of each model. Effectiveness rates were calculated for each model of trap by

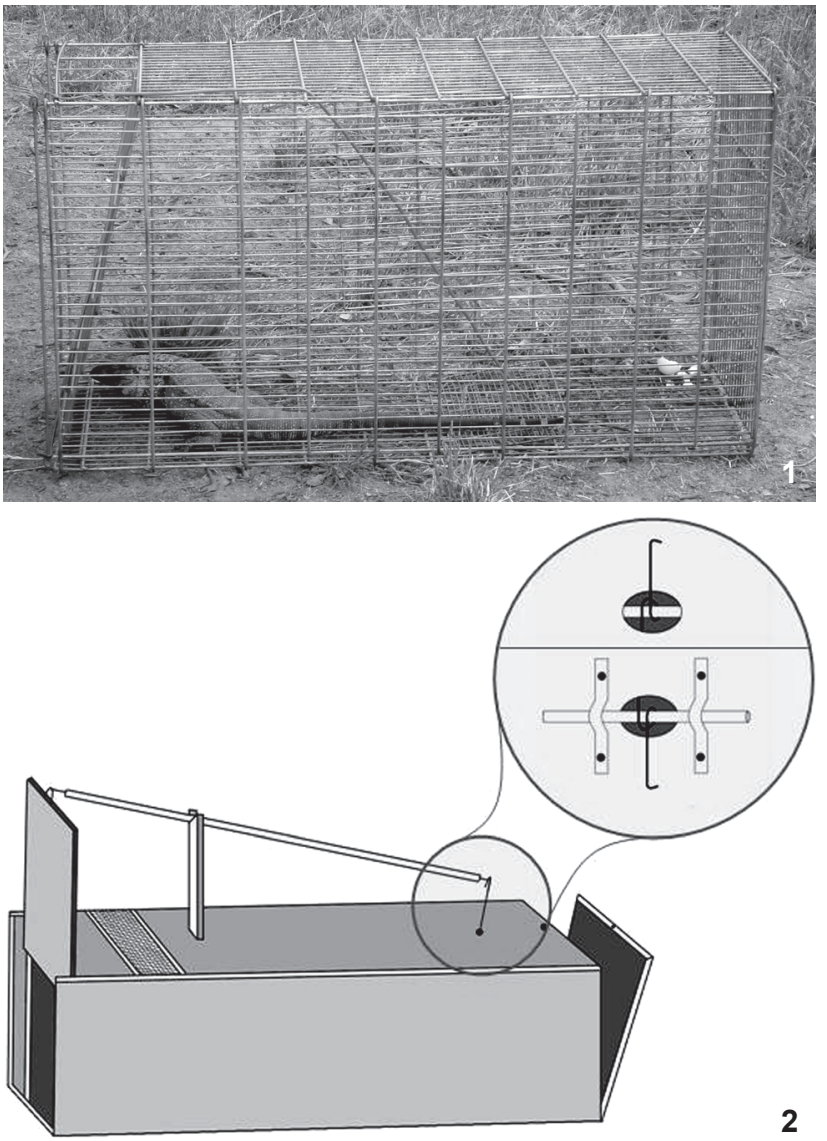

Figures 1-2. (1) Metallic trap used in the study. (2) Scheme of the wooden trap (Schramm trap) developed for the study. Photo: Arthur Schramm.

dividing the number of lizards captured in that type of trap by each method's total capture effort - adapted from the calculation of the capture effort of MAciel et al. (2003) and DAvIS \& WINSTEAD (1987). The number of males and females and adults and juveniles captured with each model of trap were compared using the Fisher test (ZAR 1999). The SVL (cm) and body mass (g) of captured lizards were compared between the trap models using the Mann-Whitney test (ZAR 1999). The analyses were performed using PAST software, version 2.17 (HAMmer et al. 2001).

The ten "Tomahawk" traps captured 74 S. merianae individuals (50 captures and 24 recaptures), with an effectiveness of 0.0152 individuals/hour. In contrast, the Schramm wooden traps captured 49 individuals, with a total effectiveness of 0.068 individuals/hour (27 captures and 22 recaptures). Thus, the Schramm wooden traps showed a capture rate of 1.63 individuals/day, whereas the "Tomahawk" traps showed an approximate rate of only 0.36 individuals/day. Importantly, recaptured individuals may have been captured the first time in a different type of trap or even through manual capture; previously 
caught lizards were captured in both trap models. Thirteen domestic animals were captured with "Tomahawk" traps, four cats and nine dogs. On the other hand, no domestic animals were captured by the Schramm traps.

When analyzing the morphological data of the individuals captured by the "Tomahawk" traps, we found that SVL varied from $20.5 \mathrm{~cm}$ to $43.5 \mathrm{~cm}$ and that body mass varied from $600 \mathrm{~g}$ to $7500 \mathrm{~g}$; the individuals caught by the Schramm trap, on the other hand, had a SVL that ranged from $22.5 \mathrm{~cm}$ to $44 \mathrm{~cm}$ and a body mass that ranged from $300 \mathrm{~g}$ to $4,750 \mathrm{~g}$. The snout-ventlength of captured individuals differed significantly between the two trap types $(\mathrm{U}=34.5, \mathrm{df}=114, \mathrm{p}=0.005)$, but their weight $\operatorname{did} \operatorname{not}(\mathrm{U}=1173, \mathrm{df}=107, \mathrm{p}=0.142)$ (Figs. 3-6). No significant differences were found in the capture frequency of males and females $\left(\chi^{2}=1,536, \mathrm{df}=1, \mathrm{p}=0.2903\right)$, but a significant difference between the two models of traps was found in the capture frequency of adults and juveniles $\left(\chi^{2}=13.99, \mathrm{df}=1, \mathrm{p}=0.000\right)$.

In the "Tomahawk" traps, 58 injured and a single dead animal were observed. On January 19, 2014, at about midday, one adult female of $S$. merianae was found dead in a "Tomahawk" trap. The temperature of the "Tomahawk" trap was $45^{\circ} \mathrm{C}$ (substrate) and $31.4^{\circ} \mathrm{C}$ (air). In similar conditions (same day, time and substrate), we recorded a substrate temperature of $30^{\circ} \mathrm{C}$ in a Schramm trap.

Reptiles are widely sampled and are usually better detected using pitfall traps (which come in a wide variety) and direct observation (MORTON et al. 1988, GARDEN et al. 2007). However, large lizards usually do not fall into pitfalls, making it difficult to choose a method for this group (see CeCHIN \& MARTins 2000 for a study using pitfalls for small and average-sized lizards).

Although there have been several studies that focused on the effectiveness of different methods of sampling reptiles, these mostly refer to pitfall traps, neglecting live traps such as cages (Crosswhite et al. 1999). DoAn (1997) captured large lizard species of Tupinambis (Daudin, 1810) using large-sized Sherman traps $(88.5 \times 31 \times 31 \mathrm{~cm})$ camouflaged in the environment. However, the capture effectiveness for those lizards was not reported.

The Schramm trap was able to capture smaller individuals than the "Tomahawk" trap (we found a significant difference between the sizes of the captured individuals and between the number of juveniles and adults). We observed that some juvenile lizards were not captured in the "Tomahawk" traps, either because they jumped over the triggering pedal to eat the bait or because they were very light, thus rendering the triggering mechanism of the "Tomahawk" trap ineffective (even though there were no significant differences in the body mass of the captured lizards).

The wooden trap presented here as an alternative for capturing $S$. merianae has the advantage of immobilizing adult individuals while not causing trauma during the capture process. In addition, the Schramm trap impedes the captured individual from seeing the researcher approaching the trap, thus limiting the animal's stress responses (MANGINI \& NicOla 2006). Another ad-
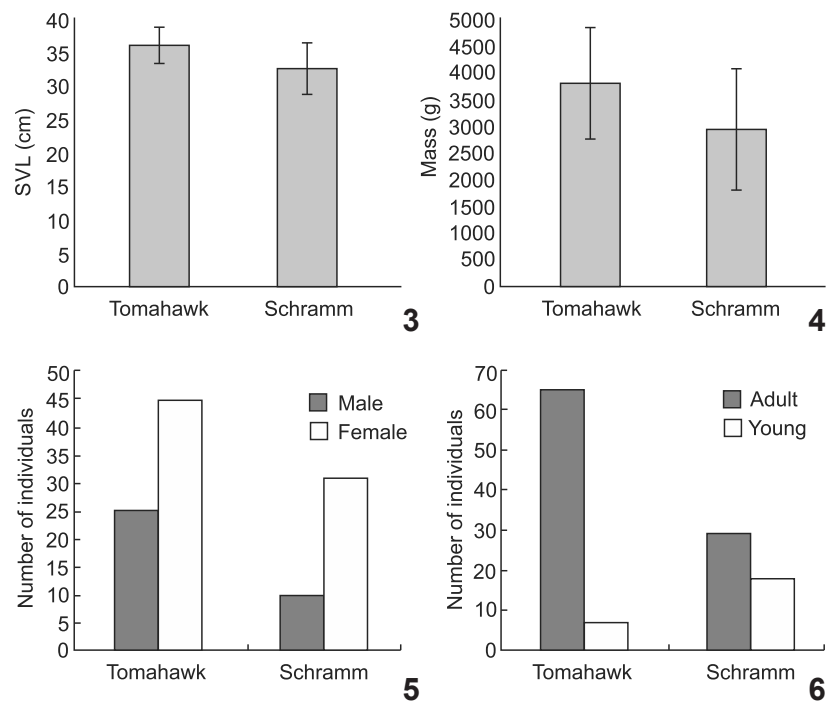

Figures 3-6. Distribution of captures in both types of trap used according to (3) size, (4) weight, (5) gender, and (6) age, at Eldorado do Sul, RS, Brazil.

vantage related to the wooden trap is that it maintains a favorable temperature for the activity of the studied species. Because they are made out of metal, the "Tomahawk" traps used are prone to overheating, eventually leading to trauma or death of the animals captured. Yet another observed advantage of wooden traps was the fact that no domestic animals were captured by them. They are small enough to hinder their entry while allowing in individuals in the size range of $S$. merianae. The "Tomahawk" traps captured domestic animals, causing bait loss and damage to the trap's structure when they attempted to escape.

On the other hand, there are some disadvantages associated with the wooden trap that should be taken into consideration. First, this trap cannot be dismantled, which makes it difficult to transport it over long distances. The "Tomahawk" traps, on the other hand, can be folded and are easier to transport. In addition, the resistance of the wooden traps may be lower because sites that are very humid or experience a high frequency of rain can decrease the resistance of the material.

Even though we did not initially intend to test different trapping mechanisms for $S$. merianae, our results indicate that the use of wooden traps can be an alternative strategy to increase capture efficiency for $S$. merianae. This strategy may also be effective for other species with similar eco-morphological features. Unquestionably, our results do not suggest the "definitive best choice" of trap for all future studies, but they provide a comparison with the aim of informing and improving the future selection of methods for capturing lizards.

In addition, the fact that $S$. merianae has been reported as having invasive potential in some parts of the world (KLUG et al. 2015), highlights the importance of finding efficient cap- 
ture techniques for it. The information presented in this study regarding the success and effectiveness of these two models of trap in capturing lizards is important in widening our understanding of the methods used in research. We believe that this work makes an important contribution for researchers working with large lizards. We recommend that all researchers publish their successes and problems in wildlife surveys to widen our understanding of the usefulness and effectiveness of different methods in the capture of different species in diverse types of habitat. We are grateful to Mr. Paulo César de Oliveira for his help in preparing the material utilized.

\section{LITERATURE CITED}

Bergamaschi H, Guadagnin ML (1990) Agroclima da Estação Experimetal Agronômica. Porto Alegre, Departamento de Plantas Forrageiras e Agrometereologia, 90p.

Campbell HW, Christman SP (1982) Field techniques for herpetofaunal community analysis, p. 193-200. In: ScotT-JR NJ (Ed.). Herpetological communities: a Symposium of the Society for the Study of Amphibians and Reptiles and the Herpetologists League. Washington, D.C., U.S. Fish Wildlife Service.

Cechin SZ, Martins M (2000) Eficiência de armadilhas de queda (pitfall traps) em amostragens de anfíbios e répteis no Brasil. Revista Brasileira Zoologia 17(3): 729-740. doi: 10.1590/ S0101-81752000000300017

Crosswhite DL, Fox SF, Thill RE (1999) Comparison of Methods for Monitoring Reptiles and Amphibians in Upland Forests of the Ouachita Mountains. Proceedings of the Oklahoma Academy of Science 79: 45-50.

Davis DE, Winstead RL (1987) Estimación de Tamaños de Poblaciones de Vida Silvestre, p. 312-344. In: Tarrés RR (Ed.) Manual de Técnicas de Gestión de Vida Silvestre. Maryland, WWF.

DoAn TM (1997) A new trap for the live capture of Large Lizards. Herpetological Review 28(2): 79.

Garden JG, McAlpine CA, Possingham HP, Jones DN (2007) Using multiple survey methods to detect terrestrial reptiles and mammals: what are the most successful and cost-efficient combinations? Wildlife Research 34(3): 218-227. doi: 10.1071/WR06111

Gibbons JW, Semlitsch RD (1981) Terrestrial drift fences with pitfall traps: an effective technique for quantitative sampling of animal population. Brimleyana 7: 1-6.

Greenberg CH, Nearly DG, Harris LD (1994) A comparison of herpetofaunal sampling effectiveness of pitfall, single-ended, and double-ended funnel traps used with drift fences. Journal of Herpetology 28(3): 319-324. doi: 10.2307/1564530

Hammer $\varnothing$, Harper DAT, Ryan PD (2001) PAST: Paleontological statistics software package for education and data analysis. Palaeontologia Electronica 4(1): 9p. Available online at: http://palaeo-electronica.org/2001_1/past/issue1_01.htm
[Accessed: 3/4/2015]

Klug Pe, Reed RN, Mazzotti FJ, McEachern MA, Vinci JJ, Craven KK, Yackel Adams AA (2015). The influence of disturbed hábitat on the spatial ecology of Argentine black and White tegu (Tupinambis merianae), a recent invader in the Everglades ecosystem (Florida, USA). Biological Invasions 17(6):1785-1797. doi: 10.1007/s10530-014-0834-7

Maciel AP, Di-Bernardo M, Hartz SM, Oliveira RB, Pontes GMF (2003) Seasonal and daily activity patterns of Liophis poecilogyrus (Serpentes: Colubridae) on the north coast of Rio Grande do Sul, Brazil. Amphibia-Reptilia 24(2): 189200. doi: $10.1163 / 156853803322390435$

MangIN PR, Nicola PA (2006) Captura e marcação de animais silvestres, p. 91-124. In: Cullen JR L, Rudran R, Valladares-Padua C (Orgs.)Métodos de estudos em Biologia da Conservação \& Manejo da Vida Silvestre. Curitiba, Ed. Universidade Federal do Paraná.

Mengak MT, GuYnn JR DC (1987) Pitfall and snap traps for sampling small mammals and herpetofauna. American Midland Naturalist 118(2): 284-288. doi: 10.2307/2425786

Morton SR, Gillam MW, Jones KR, Fleming MR (1988) Relative efficiency of different Pit-Trap Systems for Sampling Reptiles in Spinifex Grasslands. Australian Wildlife Research 15(5): 571-577. doi: 10.1071/WR9880571

Oliveira G de, Passipieri M, Altimare AL, Feba LGT (2007) Eficiência das armadilhas dos tipos tomahawk e pitfall na captura de pequenos mamíferos. In: Anais do VIII Congresso de Ecologia do Brasil: 1-2.

ReED RN, Morton JM, Desy GE (2000) Use of Monofilament Snare Traps for Capture of Varanid Lizards. Micronesica 33(1/2): 99-104.

SCHEMNITZ SD (2005) Capturing and handling wild animals, p. 239285. In: BRAUN CE (Ed.). Techniques for wildlife investigations and management. Bethesda, The Wildlife Society.

Souza CA, Lima SC, Pederassi J (2011) Contribuição metodológica na confecção de armadilhas iscadas para lagartos em ecossistemas de restinga, Angra dos Reis, Rio de Janeiro. Ecologia 2: 42-45.

Thomas AL, Costa JA, Pires JL (1998) Rendimento de grãos de soja afetado pelo espaçamento entre linhas e fertilidade do solo. Ciência Rural 28(4): 543-546.

VAnzolini PE, PAPAVERo N (1967) Manual de coleta e preparação de animais terrestres e de água doce. São Paulo, Secretaria da Agricultura do Estado de São Paulo.

Winck GR, Blanco CC, CeChIn SZ (2011) Population ecology of Tupinambis merianae (Squamata, Teiidae): home-range, activity and space use. Animal Biology 61(4): 493-510. doi: 10.1163/157075511X597647

ZAR JH (1999) Biostatistical Analysis. New Jersey, Prentice Hall, $663 p$.

Submitted: 8 October 2014

Received in revised form: 9 April 2015

Accepted: 1 June 2015

Editorial responsibility: Diego Astúa de Moraes 